\title{
Hand Washing Activities Based on Text Messages and Phone Call Intervention to Housewives at Coastal Region of Bagan Delivillage
}

\author{
Evi Naria ${ }^{1}$, Ade Candra ${ }^{2}$ \\ ${ }^{I}$ Public Health Faculty, University of Sumatera Utara, Indonesia \\ evi3@usu.ac.id \\ ${ }^{2}$ Computer Science and Information Technology Faculty, University of Sumatera Utara, Indonesia
}

ade_candra@usu.ac.id

\begin{abstract}
Indonesia sanitation problem is claimed as the second worst in the world, although Community Total Led Sanitation (CLTS) program has been implementated since 2008. Once of CLTS activity is hand washing with soap. Data from Community Health Development Index (2010) show that hand washing practice is still low, only $24,5 \%$. Hand washing with soap could reduce $45 \%$ chance of diarrhea. The study aims to determine the difference hand washing with soap activity based on text messeges and phone calls to housewives at coastal region. Type of research is quasi experiment with pre andpost test. Text messages and phone calls intervention were done to three housewives group. First was control, second was text messages intervention, and third was phone calls intervention, with 25 persons per group. Data analysis is done with paired t-test and ANOVA on $95 \%$ of confidence level. The result shows that $36 \%$ of housewife'sage is between 31 - 40 years old. Hand washing before eating were done by $42,7 \%$ to $54,7 \%$ of housewives, before foodpreparation $16 \%$ to $26,7 \%$, after defecate $36 \%$ to $49,3 \%$ before and after intervention. There are significant t-tests with p-value 0,001. ANOVA showssignificant difference in the control, text messages, and phone calls with p-value 0,001 . Text messages and phone calls intervention has no significant difference and explicitly effective as intervention to improve hand washing behavior.
\end{abstract}

Keywords - Hand Washing, Text Messages, Phone Calls, Housewives, Bagan Deli

\section{INTRODUCTION}

Sanitation is an effort to control all factors of human physical environment which may cause adverse things for physical development, health, and survival of human beings. Based on survey of Water Sanitation Program (WSP) it was stated by United Nations 2013 that Indonesia is a country with the world's second worst sanitation.Sanitation issues according to the Working Group of the National Water Supply and Environmental Health 2010 are $22.29 \%$ of the population do not have access to drinking water and more than 70 million people do not have access to basic sanitation. Awareness for clean and healthy behavior is still low.

The government is already working on the improvement of public sanitation through Total Sanitation based on People program to change behavior toward hygienic sanitationwhich focus on community empowerment. Total Sanitation based on People program includes five pillars which are (1) do not defecate arbitrary, (2) wash hands with soap, (3) manage drinking water and food safely, (4) manage waste properly, (5) managehouseholds'seffluentsafely [1]. Target to achieve is universal access on Indonesian sanitation in 2019.

One of Total Sanitation based on People program is handwashing with soap. Data from the Community Health Development Index 2010 [2], handwashing with soap in the society is still very low at $24.5 \%$. Handwashing with soap can reduce the incidence of diarrheal disease by $45 \%$.

Handwashing with soap proved to be an effective way to preventive health, and deemed as most strategic way to reduce losses impact caused by poor sanitation, so it should be encouraged to become a way life in the entire community [3]

We recommend five important time for handwashing, namely after defecation, before eating, before feeding the baby or feeding infant and child, after cleaning a baby, after holding the animals or pets.

Any kind of soap can be used for handwashing such as soap for regularbath, antiseptic soap, or liquid soap. 
But antiseptic / antibacterial soap is promoted more often in public. Up to now there is no research to prove that certain antiseptic soap or disinfectant can make a person susceptible to organisms that are general in nature [4].

Seven stepsof good and right way for handwashing with soap are: (1) Moisten both hands as high as the mid-arm with flowing water, grab the soap and then wipe and rub your palms together gently. (2)Wipe and rub the back of the hand alternately, (3) Do not forget to rub between the fingers, (4) Clean the fingertips interchangeably with clenched, (5) Rub and turn both thumbs alternately, (6) Place the fingertips to the palm and then rub gently, (7) Clean both wrists alternately by rotating, then stopped with the whole hand rinse with clean running water and dry with towels or wipes.According [5] that lack of compliance factorsfor handwashing in individual are (a) Lack of knowledge and experience, (b) Limited knowledge about guidelines for hand hygiene, (c) Lack of understanding in the risks of pathogenmicroorganisms transmission from hands, (d) Hand skin irritation to usedmaterials.

The sanitation problem occurs at coastal areas. This area generally has a dense population, slums, and predominately by fishermen. Community Sanitation assistance program has been conducted in this area. Manullang [6] showed that Community Sanitation assistance program has been done, however in terms of empowerment, the community has not entirely empowered because the lack of guidance from various parties.

Empowerment and people's self-reliance in improving health should be pursued continuously. One way is to utilize the community-owned means of communication, like the telephone which is currently owned by almost everyone.

SMS service is a type of service that is "no - real time" as when a short message sent to a destination, if the destination is not active then the delivery will be delayed to destination until it is active again. Basically SMS is guaranteed to get to the destination. Temporary delivery failure as inactive destination will always be identified so that retransmission SMS will always be possible unless the SMS which has been given a certain time and still overdue it should be removed and stated fail to send [7].

The advantage of SMS usage are as follows: (a) Only requires a mobile phone without any other supporting devices, (b) sending a message is relatively fast, (c) The cost of sending SMS is relatively inexpensive, (d) Comfort, messages can be stored in the mobile phone until the user has time to read, (e) If the recipient's mobile phone messages in off, then as soon as the mobile phone is on the messages that have been sent are received, (f)SMS messages can be broadcasted to various destinations [7].

Communication via the telephone has an idea to speak and listen from a distance. As a means of communication, the phone can be used to convey and receive information quickly at the same time.

Advantages of communication via telephone: (a) The speed of getting information, rather than write a message, (b) Costs can be estimated since the usage is based on the time of communication, (c) Personal relationships, even without face-to-face, (d) The response to information submitted can be done immediately, so that the receipt or denial of information can be known immediately.

Problems that could arise on a phone call (a) Bad device so the sound is not clear, (b)The connection can be interrupted when talks are underway, (c) Did not hear when the phone is rings

Herlina's study [8] on the use of Short Messege Service (SMS) as a medium for health promotion proved effective in increasing knowledge of pregnant women in complications and nutritional intake during pregnancy. Information over the phone has its advantages. The information can be delivered quickly, relatively cheap, and the service is definitely exist on every mobile phone.

Based on data collected by the Indonesian Cellular Telecommunications Association (ATSI) until the end of 2011 mobile usage penetration in Indonesia is approximately 250 million, or $110 \%$ of Indonesia's population and the number of SMS messages sent in 2011 has reached 260 billion SMS. The number of cell phone usage potential as a health promotion media that could provide enough benefits for community [8]. 


\section{RESEARCH METHODS}

Knowing the effectiveness of interventions text messages and phone calls on the activities of handwashing with soap at housewives.

The research type is quasi-experimental with pre and post test design. This study consisted of two interventions which are text messagesand phone calls, as well as one as control.

Population is housewives from three populous neighbourhood. In this study, a sample of 25 housewives for each intervention, and 25 housewives as a control. The total sample are 75 housewives.

Sample was determined by purposive with following criteria: (a) Residing and registered as local residents, (b) Willing to be a respondent during the study period, (c) Has minimal complete primary school education, (d) has its own mobile phone

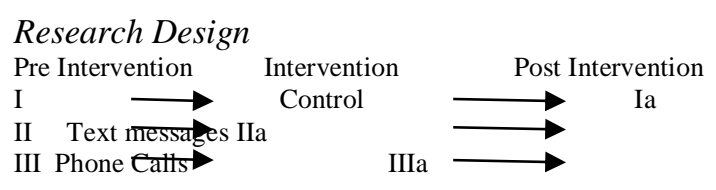

Research Stages:

1. Collection of respondents characteristics data

2. Observation of respondent hand washing facilities
3. Pre intervention data collection on hand washing with soap. Hand washing covering means variables and when handwashing with soap include handwashing with soap before eating, after defecation, before feeding the baby, after feeding the baby, before preparing food and after handling animals.

4. Collect the respondents to provide information about handwashing with soap.

5. Intervention by text messagesabout hand washing information for 10 days

6. Intervention by phone calls about hand washing information are performed once per 2 days, for 10 days

7. Post intervention data collection on handwashing with soap

Data Analysis with univariate and bivariat. Univariate, used to describe distribution and proportion of each studied variable. Intervention data were analyzed with the Wilcoxon test to see the difference before and after intervention in each treatment group, and Kruskal Wallis to see the difference between one group with another at $95 \%$ confidence level.

\section{RESULT AND DISCUSSION}

\section{A. Characteristics of Respondents}

Characteristics of respondents in Bagan Deli village can be seen in the following table.

TABLE I.

CHARACTERISTICS OF RESPONDENTS AT COASTAL REGION OF BAGAN DELI VILLAGE

\begin{tabular}{|c|c|c|c|c|c|c|c|c|c|}
\hline \multirow[t]{2}{*}{ No. } & \multirow[t]{2}{*}{ Characteristic } & \multicolumn{2}{|l|}{ Control } & \multicolumn{2}{|c|}{$\begin{array}{c}\text { Intervention } \\
\text { by text messages }\end{array}$} & \multicolumn{2}{|c|}{$\begin{array}{c}\text { Intervention by } \\
\text { phone calls }\end{array}$} & Total & $\%$ \\
\hline & & \multicolumn{2}{|c|}{ n\% } & \multicolumn{2}{|c|}{ n\% } & \multicolumn{2}{|c|}{ n\% } & & \\
\hline \multicolumn{10}{|c|}{ Age (year) } \\
\hline 1 & $21-30$ & 9 & 36.0 & 7 & 28.0 & 6 & 24.0 & 22 & 29.3 \\
\hline 2 & $31-40$ & 10 & 40.0 & 7 & 28.0 & 10 & 40.0 & 27 & 36.0 \\
\hline 3 & $41-50$ & 5 & 20.0 & 9 & 36.0 & 5 & 20.0 & 19 & 25.3 \\
\hline \multirow[t]{2}{*}{4} & $>50$ & 1 & 4.0 & 2 & 8.0 & 4 & 16.0 & 7 & 9.3 \\
\hline & & & & & & & & 75 & 100.0 \\
\hline \multicolumn{10}{|c|}{ Education } \\
\hline 1 & Elementary School & 6 & 24.0 & 9 & 36.0 & 7 & 28.0 & 22 & 29.3 \\
\hline 2 & Junior High School & 8 & 32.0 & 5 & 20.0 & 6 & 24.0 & 19 & 25.3 \\
\hline \multirow[t]{2}{*}{3} & Senior High School & 11 & 44.4 & 11 & 44.0 & 12 & 48.0 & 34 & 45.3 \\
\hline & & & & & & & & 75 & 100.0 \\
\hline \multicolumn{10}{|c|}{ Long of stay at home (year) } \\
\hline 1 & $0-5$ & 7 & 28.0 & 6 & 24.0 & 9 & 36.0 & 22 & 29.3 \\
\hline 2 & $6-10$ & 4 & 16.0 & 4 & 16.0 & 3 & 12.0 & 11 & 14.7 \\
\hline 3 & $11-15$ & 1 & 4.0 & 3 & 12.0 & 2 & 8.0 & 6 & 8.0 \\
\hline 4 & $16-20$ & 4 & 16.0 & 4 & 16.0 & 1 & 4.0 & 9 & 12.0 \\
\hline 5 & More than 20 & 9 & 36.0 & 8 & 32.0 & 10 & 40.0 & 27 & 36.0 \\
\hline
\end{tabular}




\begin{tabular}{|l|l|r|r|r|r|r|r|r|r|}
\hline \multicolumn{2}{|l|}{} & & & & & & & & \\
\hline \multicolumn{2}{|c|}{ Respondent's Job } & & & & & & & \\
\hline 1 & $\begin{array}{l}\text { At home (home } \\
\text { industry, } \\
\text { entrepereneur) }\end{array}$ & 22 & 88.0 & 23 & 92.0 & 24 & 96.0 & 69 & 92.0 \\
\hline 2 & $\begin{array}{l}\text { Outside } \\
\text { (labour, fisherman) }\end{array}$ & 3 & 12.0 & 2 & 8.0 & 1 & 4.0 & 6 & 8.0 \\
\hline & & & & & & & 75 & 100.0 \\
\hline
\end{tabular}

Based on the above table shows that most respondents is in the age of 31-40 years old, which is $36.0 \%$. High School graduates is $45.3 \%$. Majority of respondents had lived in Bagan Deli over 10 years is $56 \%$. Most of respondents are housewives which is $92 \%$.

\section{B. Hand Washing Activities}

Handwashing facilities in the of Bagan Deli village before and after intervention by text messages, phone call and controls can be seen in the following table.

TABLE II.

HAND WASHING FACILITIES DESCRIPTION BEFORE AND AFTER INTERVENTION

\begin{tabular}{|c|c|c|c|c|c|c|c|c|c|c|c|c|c|}
\hline \multirow{3}{*}{$\begin{array}{l}\mathrm{N} \\
\mathrm{o}\end{array}$} & \multirow{3}{*}{$\begin{array}{c}\text { Handwashing } \\
\text { facilities } \\
\text { observation }\end{array}$} & \multicolumn{6}{|c|}{ Before intervention } & \multicolumn{6}{|c|}{ After intervention } \\
\hline & & \multicolumn{2}{|c|}{ Control } & \multicolumn{2}{|c|}{$\begin{array}{c}\text { Text } \\
\text { messages }\end{array}$} & \multicolumn{2}{|c|}{ Phone calls } & \multicolumn{2}{|c|}{ Control } & \multicolumn{2}{|c|}{ SMS } & \multicolumn{2}{|c|}{ Call by phone } \\
\hline & & $\mathrm{n}$ & $\%$ & $\mathrm{n}$ & $\%$ & $\mathrm{n}$ & $\%$ & $\mathrm{n}$ & $\%$ & $\mathrm{n}$ & $\%$ & $\mathrm{n}$ & $\%$ \\
\hline 1 & $\begin{array}{l}\text { Running water is } \\
\text { avalaible at home }\end{array}$ & 10 & 40.0 & 9 & 36 & 8 & 32 & 10 & 40 & 11 & 44 & 10 & 40 \\
\hline 2 & Soap is available & 24 & 96.0 & 24 & 96.0 & 25 & 100 & 25 & 100 & 24 & 96 & 25 & 100 \\
\hline 3 & $\begin{array}{l}\text { Handwashing } \\
\text { equipment is } \\
\text { available at home }\end{array}$ & 25 & 100 & 24 & 96 & 25 & 100 & 25 & 100 & 24 & 96 & 25 & 100 \\
\hline
\end{tabular}

The above table shows that the availability of soap and presence of handwashingequipmenthave already owned by $96 \%$ to $100 \%$ of respondents. The availability of running water for hand washing is owned by $40 \%$ of the control group before and after the intervention, on the interventiongroupstext messagesit change from $36 \%$ to $44 \%$ after the intervention, and the interventiongroups over the phonecallsit change from $32 \%$ to $40 \%$ after the intervention.

Subsequently the current handwashing with soapdata is collected. The current data on hand washing with soap can be seen in the following table.

TABLE III

DESCRIPTION OF HAND WASHING ACTIVITIES BEFORE AND AFTER TEXT MESSAGES AND PHONE CALLS INTERVENTION AS WELL AS THE CONTROL GROUP AT COASTAL REGION BAGAN DELI VILLAGE

\begin{tabular}{|c|c|c|c|c|c|c|c|c|c|c|c|c|c|}
\hline \multirow{3}{*}{ No } & \multirow{3}{*}{$\begin{array}{c}\text { Handwashing } \\
\text { with soap }\end{array}$} & \multicolumn{6}{|c|}{ Before Intervention } & \multicolumn{6}{|c|}{ AfterIntervention } \\
\hline & & \multicolumn{2}{|c|}{ Control } & \multicolumn{2}{|c|}{ Text Messages } & \multicolumn{2}{|c|}{ PhoneCalls } & \multicolumn{2}{|c|}{ Control } & \multicolumn{2}{|c|}{ Text Messages } & \multicolumn{2}{|c|}{ Phone Calls } \\
\hline & & $\mathrm{n}$ & $\%$ & $\mathrm{n}$ & $\%$ & $\mathrm{n}$ & $\%$ & $\mathrm{n}$ & $\%$ & $\mathrm{n}$ & $\%$ & $n$ & $\%$ \\
\hline 1 & Before eating & 12 & 48 & 8 & 32 & 12 & 48 & 12 & 48 & 13 & 52 & 16 & 64 \\
\hline 2 & After defecate & 8 & 32 & 8 & 32 & 11 & 44 & 7 & 28 & 13 & 52 & 17 & 68 \\
\hline 3 & $\begin{array}{l}\text { Before feeding the } \\
\text { baby }\end{array}$ & 6 & 24 & 2 & 8 & 2 & 8 & 3 & 12 & 2 & 8 & 4 & 16 \\
\hline 4 & $\begin{array}{l}\text { After cleaning up } \\
\text { baby's poop }\end{array}$ & 6 & 24 & 1 & 4 & 3 & 12 & 2 & 8 & 4 & 16 & 4 & 16 \\
\hline 5 & $\begin{array}{l}\text { Before prepare the } \\
\text { food }\end{array}$ & 6 & 24 & 2 & 8 & 4 & 16 & 4 & 16 & 7 & 28 & 9 & 36 \\
\hline 6 & After touch the pets & 0 & 0 & 1 & 4 & 2 & 8 & 2 & 8 & 2 & 8 & 3 & 12 \\
\hline
\end{tabular}

Respondents who always wash their hands before eating is $48 \%$ in the control group before and after the intervention, in intervention groups text messagesit change from $32 \%$ to $52 \%$ after the intervention, and in intervention groups phonecallsit change from $48 \%$ to $64 \%$ after the intervention.

Handwashing with soap after defecation (BAB) is done by $32 \%$ of controlledrespondentsand become 
$28 \%$ after intervention, in intervention groups text messagesit change from $32 \%$ to $52 \%$ after intervention, and in intervention groups phone calls it change from $44 \%$ to $68 \%$ after intervention. Handwashing with soap before and after feeding feeding the baby carried by $24 \%$ of respondents, it change from $8 \%$ to $16 \%$ after intervention. Hand washing before preparing the food is carried by $24 \%$ of controlledrespondents to $16 \%$ after the intervention, in intervention groups text messagesit change from $8 \%$ to $28 \%$ after intervention, and in intervention groups phonecallsit change from $16 \%$ to $36 \%$ after intervention.

TABLE IV

ANALYSIS OF HANDWASHING WITH SOAP ACTIVITY DATA BEFORE AND AFTER INTERVENTION AT COASTAL REGION OF BAGAN DELI VILLAGE, MEDAN CITY

\begin{tabular}{|c|c|c|c|c|c|c|}
\hline \multirow{3}{*}{$\begin{array}{l}\mathrm{N} \\
\mathrm{O}\end{array}$} & \multirow{3}{*}{$\begin{array}{c}\text { Handwashing } \\
\text { with soap }\end{array}$} & \multicolumn{4}{|c|}{ Intervention } & \multirow{3}{*}{$\mathrm{p}$ value } \\
\hline & & \multicolumn{2}{|c|}{ Before } & \multicolumn{2}{|c|}{ After } & \\
\hline & & $\mathrm{n}$ & $\%$ & $\mathrm{n}$ & $\%$ & \\
\hline 1 & Before eating & 32 & 42.7 & 41 & 54.7 & 0.001 \\
\hline 2 & After defecate & 27 & 36.0 & 37 & 49.3 & 0.001 \\
\hline 3 & Before prepare the food & 12 & 16.0 & 20 & 26.7 & 0.001 \\
\hline 4 & Running water is avalaible at home & 27 & 36.0 & 31 & 41.3 & 0.16 \\
\hline
\end{tabular}

The above table shows that the handwashing with soap before eating, handwashing with soap after defecating, and handwashing with soap before preparing food are variables which have value of $\mathrm{p}$ 0.001. It shows that there is a difference before and after intervention text messages and phone callsassistanceimplemented. Another variablewhich is availability ofrunning water for handwashing has $\mathrm{p}$ value more than 0.05 . This means though descriptively is seen an increase in the number of respondents in hand washingactivitiesbased on text messages and phone calls but not statistically different.

Analysis by type of intervention namely control, assistance text messages and phone calls are performed using Kruskal Wallis test at the $95 \%$ of confidence level. The results of data analysis can be seen in the following table.

TABLE V

ANALYSIS OF HANDWASHING WITH SOAP ACITIVITY DATA BASED ON INTERVENTION TYPE ATCOASTAL REGION OF BAGAN DELI VILLAGE, MEDAN CITY

\begin{tabular}{|l|l|c|}
\hline No & \multicolumn{1}{|c|}{ Handwashing with soap } & $\begin{array}{c}\text { p value } \\
\text { based on intervention }\end{array}$ \\
\hline 1 & Before eating & 0.29 \\
\hline 2 & After defecate & 0.001 \\
\hline 3 & Before prepare the food & 0.10 \\
\hline 4 & $\begin{array}{l}\text { Running water is avalaible at } \\
\text { home }\end{array}$ & 0.67 \\
\hline
\end{tabular}

The above table shows that the implementation of hand washing activities on housewives that ishandwashing with soap after defecation, which intervened by text messages and phone calls and the control group showed significantly different results with $p=0.001$. Other implementations which are handwashing with soap before eating and before preparing food, availability of running water for handwashing, showed the results were not significantly different with $p>0.05$.

Handwashing with soap after defecation variable is followed by Least Significant Difrence (LSD)advanced test to see what kind of intervention is different from each other. Advanced test results can be seen in the following table:

TABLE VI

ADVANCE ANALYSIS BETWEEN INTERVENTIONTYPE AT COASTAL REGION OF BAGAN DELI VILLAGE

\begin{tabular}{|c|c|c|c|}
\hline No & \multicolumn{2}{|c|}{ Type of intervention } & $\begin{array}{c}\text { Significance of } \\
\text { handwashing after defecate }\end{array}$ \\
\hline \multirow[t]{2}{*}{1} & \multirow[t]{2}{*}{ Control } & Text messages & 0.06 \\
\hline & & Phone calls & 0.01 \\
\hline \multirow[t]{2}{*}{2} & \multirow{2}{*}{$\begin{array}{l}\text { Text } \\
\text { messages }\end{array}$} & Control & 0.06 \\
\hline & & Phone calls & 0.44 \\
\hline \multirow[t]{2}{*}{3} & \multirow[t]{2}{*}{ Phone calls } & Control & 0.01 \\
\hline & & Text messages & 0.44 \\
\hline
\end{tabular}

The above table shows that the $\mathrm{p}$ value of control group was significantly different from intervention 
group text messages and phone calls. The intervention of text messages and phone calls are not significantly different with value of $\mathrm{p}=0.44$.

\section{Discussion}

Housewives in Bagan Deli village generally have a high school education level, and at the age of 31-40 years old, where with this level of education the housewives is expected to have ability to adopt useful information to improve the quality of healthcare in their home.

Handwashing activity increasing after the intervention. Availability of soap and presence of handwashing equipment have already owned by $96 \%$ to $100 \%$ of respondents. The availability of running water for hand washing is owned by $40 \%$ of the control group before and after intervention, on text messages interventionit changes from $36 \%$ to $44 \%$ after intervention, and with phone calls intervention it changesfrom $32 \%$ to $40 \%$ after the intervention.

Respondents who always wash their hands before eating is $48 \%$ in the control group before and after intervention, on text messages interventionchange from $32 \%$ to $52 \%$ after intervention, and with phone call intervention change $48 \%$ to $64 \%$ after intervention. Handwashing with soap after defecation is done by $32 \%$ of controlledrespondents and become $28 \%$ after intervention, on text messages intervention change from $32 \%$ to $52 \%$ after intervention, and phone calls change from $44 \%$ to $68 \%$ after the intervention.

Handwashing with soap before and after feeding the baby carried by $24 \%$ of respondents change to $8 \%$ and $16 \%$ after intervention. Handwashing before preparing food is carried by $24 \%$ of controlledrespondentsand change to $16 \%$ after intervention, text messages interventionfrom $8 \%$ to $28 \%$ after intervention, and with phone calls change from $16 \%$ to $36 \%$ after intervention.

Handwashing activity with soap before eating, after defecating, and before preparing food has a value of $p$ 0.001 . This indicates that there is a difference before and after intervention text messages and phone call simplemented. Other variables which is availability of running water for handwashing, have a p-value of more than 0.05 . This means though descriptively is seen an increase in number of respondents in handwashingctivitiesbut not statistically different.

Herlina's study [8] on the use of Short Messege Service (SMS) as a medium for health promotion proved effective in increasing knowledge of pregnant women in complications and nutritional intake during pregnancy.

Based on the type of intervention which are control, text messages and phone calls indicate that the implementation of handwashing with soap after defecation, which intervened text messages and phone calls as well as a controlled group show significantly different results with $\mathrm{p}=0.001$. Handwashing activity with soap before eating, handwashing before preparing food and availability of running water for handwashinghave shown that the results arenot significantly different from the value $\mathrm{p}>0.05$.

Handwashing with soap after defecation variable by further tests showed that the control group was significantly different from intervened text messages and phone calls. The text messages and phone calls intervention were not significantly different.

Intervention only give a little change in the households. This condition occurs for several reasons, namely the control group could have received information from other media sources in conjunction with the ongoing research activities. Information text messages or phonecallsaretoo much and different so less information embedded in memory of receiver. Research [9] on intervention with counseling, information by SMS, and phone call for disease control based on environment shows that there is a difference in latrines which eligible $(p=0.01)$ before and after intervention. Intervention bycounseling and SMS $(p=0.02)$ or phone $(p=0.01)$ in contrast to the control and counseling.

\section{CONCLUSION}

Hand washing activity increasing after text messages and phone calls intervention. Hand washing with soap before eating, after defecating, and before preparing food difference before and after text messages and phone calls intervention (p 0.001) Hand washing with soap after defecation, which intervened 
text messages and phone calls as well as, and with controlled group show significantly different $(\mathrm{p}=$ 0.001).

\section{REFERENCES}

[1] Depkes, 2014, Community Total Led Sanitation. Indonesia Ministry Health. Jakarta

[2] Community Health Development Index 2010. Badan Pusat Statistik Indonesia. Jakarta

[3] Hendrawan, N. 2009. ResepMudahTetapSehat. Penerbit Buku Kompas. Jakarta

[4] Weber DJ, Rutala WA (2006). Use of germicides in the home and the healthcare setting: is there a relationship between germicide use and antibiotic resistance.

[5] Maryunani. A, 2011. PencegahanInfeksidalamKebidanan. CV. Trams Info Media. Jakarta

[6] Manullang, Z. 2014. Evaluasi Dampak Program Sanitasi Berbasis Masyarakat (SANIMAS) Dalam Pemberdayaan Masyarakat di Kelurahan Bagan Deli Kecamatan Medan Belawan Kota Medan. Skripsi. FakultasIlmuSosialdanIlmuPolitik. Universitas Sumatera Utara. Medan

[7] Muharyani, P.W. 2011. Aplikasi Short Message Service (SMS) Dalam Promosi Kesehatan Reproduksi di Komunitas. Tesis. Program PascaSarjana.Universitas Indonesia. Jakarta

[8] Herlina, S. 2013. Keefektifan SMS Reminder Sebagai Media Promosi Kesehatan Ibu Hamil di Daerah Terpencil. Seminar Nasional Informatika Medis (SNIMed) IV. Magister Teknik Informatika. FakultasTeknologiIndustri. Universitas Islam. Jogyakarta.

[9] Naria, E. 2014. Model Intervensi Sanitasi Lingkungan Rumahdan Gizi Keluarga dalam Upaya Pengendalian Penyakit Berbasis Lingkungan pada Kawasan Kumuh Kecamatan Medan Maimun Kota Medan. Penelitian Fundamental. Universitas Sumatera Utara. Medan 